\title{
A unique culture of football
}

\author{
Ho Manh Toan \\ Phenikaa University

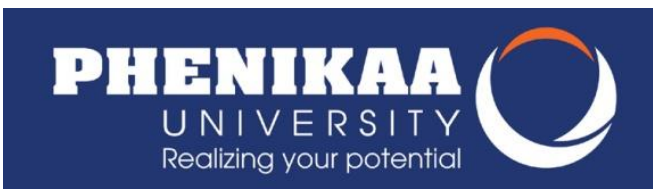 \\ Hanoi, Vietnam \\ January 13,2021
}

Hanoi Premier League, or more commonly HPL, finally found the king for season 8 on December 20, 2020 [1]. Two more years, and the tournament will be ten years old. Notably, HPL is a league for seven-a-side amateur football teams. Since the seventh season, the league is expanded to the national scale, with regional leagues in Hanoi, Khanh Hoa (Khanhhoa Premier League - KPL), and Ho Chi Minh city (Saigon Premier League - SPL). After the regional tournament conclusion, the Vietnam Premier League will be organized with champions of each region and a runner-up with the highest points [2].

Since the first season in 2013, Hanoi Premier League has attracted fans on an unimaginable scale. Back then, HPL was probably the first tournament held in the league format, which requires meticulous organization due to its length. Each Sunday, in a field without stands, many people still came and watched the games [3]. The attraction continues until now, with thousands of fans in each round [4-6]. 


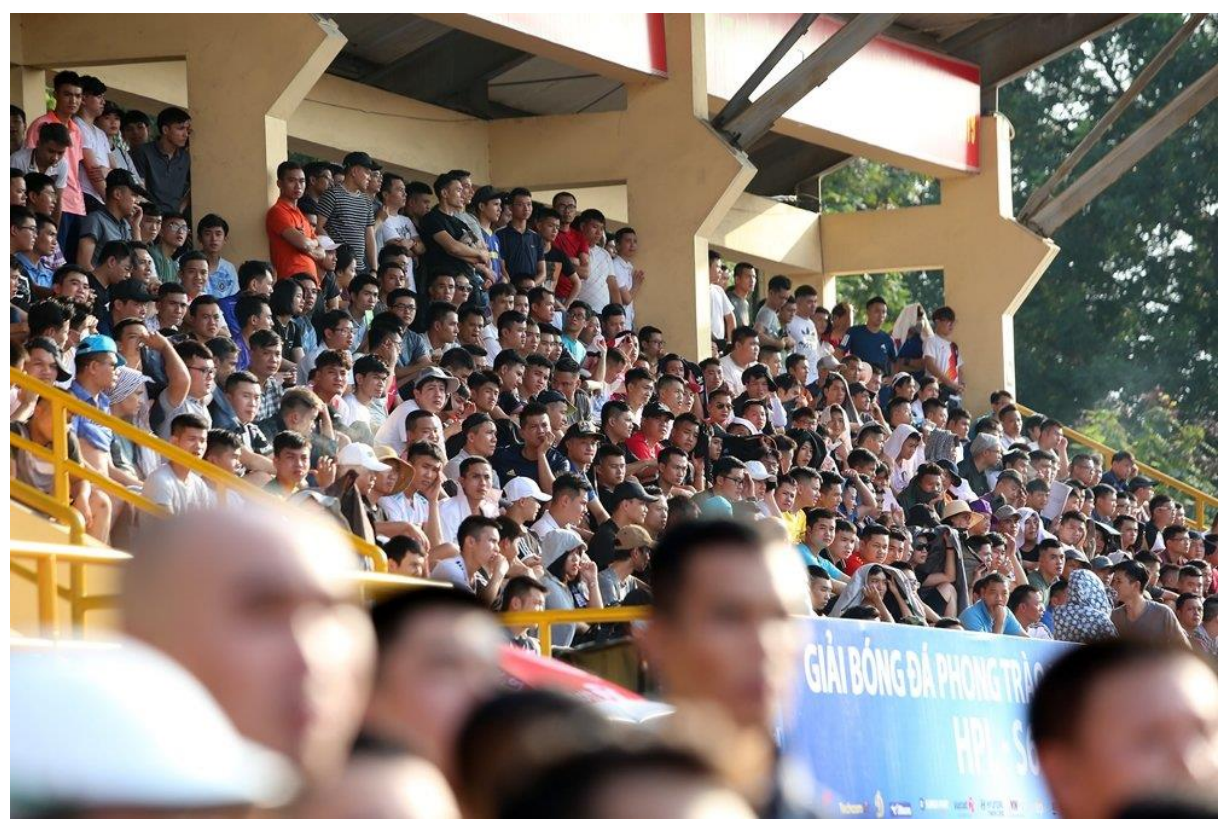

Figure 1. The audiences in HPL (Source: [5]).

The professionalization of amateur football in Vietnam is peculiar because of the way HPL becomes an unforgettable event. Many factors contribute to the popularity of HPL, from the organization's professionalism to the consistency in maintaining a brand. Meanwhile, the external factors such as the development of the economy, the decline of Vietnamese professional football, and the rise of social media are crucial to the Hanoi Premier League.

The latest IMF calculation in 2020 indicated that Vietnam's gross domestic products (GDP) had exceeded US $\$ 1,005$ billion, PPP-adjusted. Meanwhile, Vietnam's growth rate has been stable at around $6.5 \%$ in the last ten years. Even during the global financial crisis in 2007-2008, experts still had high hope for Vietnam's development $[7,8]$. The rise in the number of listed companies from only 330 in 2008 to 745 in 2019 is the most evident [9].

Thus, more money created more opportunities for companies to invest and diversify their portfolio. Sports is an attractive venture due to its publicity. Moreover, the business culture in Vietnam also values friendly activities such as a football match or casual dinner. Since 2013, HPL has gained its momentum with a 3-month long of weekly publicity. Moreover, the cost of a seven-a-side football team is much less than a professional team. Consequently, HPL is a seductive opportunity.

After becoming the Southeast Asia champion in 2008, the Vietnam national football team and the professional football in Vietnam started to decline. 
Low quality, match-fixing, violence, or fan-less stands have plagued Vietnamese football [10-12]. It was not until 2013 that a new generation of young footballers ignited a new hope. Amidst that situation, it is understandable that Vietnamese people find a new source of relaxation. Hanoi Premier League, despite being an amateur football tournament, was able to supply that pureness.

Moreover, due to football's bleak situation in Vietnam at that time, many academy players decided to quit professional football and started playing for company teams. Along with the needs of the companies, a semi-professional environment has been created. A company can have a strong football team. Meanwhile, a player can have a stable job and some extra bonuses.

However, companies' interest in football and players' need has always happened. The final push for the popularity of HPL was probably the rise of social media and its livestream function. HPL was the first amateur tournament in Vietnam to record all of its games and reupload them to YouTube as highlights. In its second season, the organizer used a bolder move: live broadcast half of its games. Suddenly, even though I was in Japan during that time, I could still watch HPL live. Unlike professional football, which is often exclusive to television, HPL provides free games to the audience. Then, livestream becomes a normalized function on Facebook, allowing more people to make use of the technology. Currently, livestreaming games have become a must for amateur tournaments, at least from the knockout rounds. Certain clubs also capitalize on the power of social media by having Facebook pages and YouTube channels.

Up to this day, I still do not know why people in Hanoi play seven-a-side football. Probably, the size of the field back then was limited. However, the high level of cultural additivity has allowed people to adapt and then slowly, turning it into something unique [13]. It seems hard to understand, but just enjoy the football [14] and let the mindsponge work for you $[15,16]$.

\section{References}

[1] Lãng, Y. (2020). Bế mạc HPL-S8: Du Lịch lần đầu lên ngôi vô địch. Web Thể Thao. Retrieved from https://webthethao.vn/bong-da-viet-nam/be-mac-hpls8-du-lich-lan-dau-len-ngoi-vo-dich-D3u3EmbMg.htm

[2] VTV. (2019). Giải bóng đá 7 người vô địch toàn quốc có thể mở rộng ra quy mô Đông Nam Á. VTV. Retrieved from https://vtv.vn/the-thao/giai-bong-da7-nguoi-vo-dich-toan-quoc-co-the-mo-rong-ra-quy-mo-dong-nam-a20191219165006.htm 
[3] Hiếu, V. A., and Tuấn, K. (2013). Khán giả đội nắng tới sân xem sao bóng đá "tắt điện" trước dân "phủi". Kênh 14. Retrieved from https://kenh14.vn/sport/khan-gia-doi-nang-toi-san-xem-sao-bong-da-tatdien-truoc-dan-phui-20130610025754260.chn

[4] Đăng, P. (2020). Hồi ức về ngày khai mạc HPL-S2. Vietfootball. Retrieved from https://vietfootball.vn/chuyen-dong-bong-da-phui/hoi-uc-ve-ngay-khaimac-hpl-s2.html

[5] Dương, N. (2018). Hàng ngàn khán giả đổ đến sân xem Ngoại hạng Phủi Hà Nội. VTC News. Retrieved from https://vtc.vn/hang-ngan-khan-gia-do-densan-xem-ngoai-hang-phui-ha-noi-ar432391.html

[6] Minh, H. (2020). Khán giả cuồng nhiệt ngày VPL-S2 hạ màn, đón chào tân vương Song Hùng. Lao Động. Retrieved from https://laodong.vn/photo/khan-gia-cuong-nhiet-ngay-vpl-s2-ha-man-donchao-tan-vuong-song-hung-865801.Ido

[7] Chính, P. M., \& Hoàng, V. Q. (2008). Bối cảnh tài chính Việt Nam 1997-1998 và 2007-2008: Khoảng cách và biến đối. Nghiên cứu Kinh tế, 48(7), 3-24.

[8] Chính, P. M., \& Hoàng, V. Q. (2009). Kinh tế Việt Nam: Thăng trầm và đột phá. Nxb Chính trị Quốc gia, Hà Nội.

[9] The Global Economy. (2021). Vietnam: Listed companies. The Global Economy. Retrieved from https://www.theglobaleconomy.com/Vietnam/Listed companies/

[10] Huy, Đ. (2011). Vấn đề của bóng đá Việt Nam: Chợ chiều V-League. Pháp Luật. Retrieved from https://plo.vn/the-thao/van-de-cua-bong-da-viet-namcho-chieu-vleague-114701.html

[11] Thạch, M. (2014). Nỗi buồn từ khán đài. Tin Thể Thao. Retrieved from https://www.tinthethao.com.vn/noi-buon-tu-khan-dai-d224404.html

[12] Vuong, Q. H., et al. (2020). On how religions could accidentally incite lies and violence: Folktales as a cultural transmitter. Palgrave Communications, 6, 82 .

[13] Vuong, Q. H., et al. (2018). Cultural additivity: Behavioural insights from the interaction of Confucianism, Buddhism, and Taoism in folktales. Palgrave Communications, 4, 143. 
[14] Vietfootball Media. (2021). Vietfootball Media [Video]. YouTube. Retrieved from https://www.youtube.com/channel/UCyViVny0SwJtHQ7ZPOK RPA

[15] Vuong, Q. H., \& Napier, N. K. (2015). Acculturation and global mindsponge: an emerging market perspective. International Journal of Intercultural Relations, 49, 354-367.

[16] Vuong, Q. H. (2016). Global mindset as the integration of emerging sociocultural values through mindsponge processes: A transition economy perspective. In J. Kuada (ed.) Global Mindsets: Exploration and Perspectives (pp. 109-126). London: Routledge. 